\title{
Effect of Pretreatments on Microbial Growth and Sensory Properties of Dry-Salted Olives
}

\author{
NURCAN DEĞIRMENCIOĞLU, ${ }^{1 *}$ OZAN GÜRBÜZ, ${ }^{2}$ ALI DEĞIRMENCIOĞLU, ${ }^{3}$ AND SEMANUR YILDIZ ${ }^{4}$
}

\begin{abstract}
${ }^{1}$ Department of Food Technology, Bandirma Vocational School, and ${ }^{3}$ Susurluk Vocational School, University of Balıkesir, Ballkesir, Turkey; ${ }^{2}$ Department of Food Engineering, Agricultural Faculty, University of Uludag, Bursa, Turkey; and ${ }^{4}$ Department of Food Engineering, Faculty of Engineering, Izmir Institute of Technology, 35430 Urla, İmir, Turkey
\end{abstract}

MS 14-036: Received 21 January 2014/Accepted 23 April 2014

\begin{abstract}
The effect of various washing solutions (acetic acid, lactic acid, and chlorine dioxide) and $\mathrm{NaCl}$ concentrations $(2.5,5.0$, and $10.0 \%$ ) on the stability of dry-salted olives (cultivars Gemlik and Edincik) during storage was studied. Vacuum-packed olives were stored at $4^{\circ} \mathrm{C}$ for 7 months and monitored for microbiological changes that occurred in the dry-salted olives during the drysalting process and for their stability during storage. Microbial populations were enumerated using pour plating (for aerobic plate counts) and spread plating (for counts of lactic acid bacteria and yeasts and molds). Aerobic plate counts were $<2.5 \mathrm{log}$ CFU/g for olive samples washed in chlorine dioxide at all $\mathrm{NaCl}$ concentrations. At $4^{\circ} \mathrm{C}$, the population of yeasts and molds increased steadily during the shelf life in Gemlik olive samples washed with all of the solutions, except chlorine dioxide, whereas yeast and mold counts in Edincik olives decreased depending on the increase in salt concentration. Therefore, different combinations of organic acids, $\mathrm{NaCl}$, and vacuum packaging can be successfully used to control the growth of yeasts and molds in these olives. The combination of vacuum sealing (with a $10-\mathrm{ppm}$ chlorine dioxide wash) and storage at $4{ }^{\circ} \mathrm{C}$ was the most effective approach for controlling the growth of lactic acid bacteria and yeasts and molds. Members of the sensory panel considered saltiness to be appropriate at 2.5 and $5.0 \% \mathrm{NaCl}$. Softness and bitterness scores increased with reduced $\mathrm{NaCl}$ concentrations, but rancidity and hardness scores increased as $\mathrm{NaCl}$ concentration increased.
\end{abstract}

Table olives are an important fermented food category, with an estimated worldwide production of 2,345,000 tons during the 2010 to 2011 season (31). Various types of table olives are produced with industrial treatments, e.g., green olives treated with alkali (Spanish style), ripe olives treated with alkaline oxidation (California style), and untreated or directly brined olives (green, turning color or naturally black) $(6,16,25,38,51)$. Table olives prepared by traditional processes (e.g., dry salted or cracked) can be found in local markets according to consumers' demands (16). The most common two Turkish olive varieties, Gemlik and Edincik (or Edincik-Su), constitute the majority of the olive production in Turkey and are best suited for producing natural black olives for use as table olives. One type of black olive is prepared as either fermented olives (Gemlik style) or dry-salted olives (Sele style). Dry salting is also used in the Mediterranean region (Greece and some North African countries) for the production of naturally preserved black olives $(18,19)$. Table olives may be processed in many other ways according to fermentation conditions of the dry-salting processes $(5,19,25,37,38,46)$. Modern food processing technologies often rely on nonthermal

\footnotetext{
* Author for correspondence. Tel: +90 266 7149302; Fax +90 266 7149304; E-mail: nurcan.degirmencioglu@gmail.com, dnurcan@balikesir. edu.tr.
}

processes to provide food products that are microbiologically safe and stable (43).

Sodium chloride $(\mathrm{NaCl})$ has long been employed in the preservation of food commodities and as a flavoring agent to enhance the organoleptic properties of food (25). The preparation of fermented vegetables in particular relies on the use of common $\mathrm{NaCl}$ as the main ingredient of the brine to reduce the water activity, increase the ionic strength of the solution, reduce the solubility of oxygen in water, and inhibit spoilage and pathogenic microbiota, thus ensuring the microbiological safety of the final product during storage (2).

For the production of dry-salted olives (basket style), the olives are harvested in December when they are fully mature and completely black. This traditional processing method consists of placing the olives in a basket, bag, or plastic container with coarse $\mathrm{NaCl}$ (4 to $10 \%$, wt/wt). The container is turned over every other day. Because of the high osmotic pressure exerted by the $\mathrm{NaCl}$ (curing or desiccating agent), the olives lose water and other solutes, including much of the bittering agent oleuropein, and become gradually debittered and wrinkled $(16,28,37)$. The low water activity ( 0.75 to 0.85 ) and high $\mathrm{NaCl}$ content of the flesh (4 to $10 \mathrm{~g} / 100 \mathrm{~g}$ ) of the dry-salted olives can ensure their safety during storage, although some spoilage microorganisms, mainly fungi, can grow under these 
conditions. Spoilage may occur when olives are not dried enough because of insufficient salt $(16,38,39,49)$.

Organic acids can be naturally present in fruits and vegetables or synthesized by microorganisms during fermentation. These acids have antimicrobial activity and are generally recognized as safe $(1,52)$. The antimicrobial activity of organic acids is attributed to $\mathrm{pH}$ reduction, depression of the internal $\mathrm{pH}$ of the microbial cells by ionization of undissociated acid molecules, chain length, cell physiology and metabolism, and disruption of substrate transport by altering the permeability of the cell's membrane $(12,34)$ or reduction of the proton motive force (22). Weak organic acids are more inhibitory for microorganisms than are strong acids. However, this effect depends on the type of acid used, the $\mathrm{pH}$ of the medium, and the concentration and temperature of the acid solution; the cell interior becomes acidified by becoming lipophilic $(1,43)$. The type of food product and the initial microbial load also affect antimicrobial activity. Acetic and lactic acid seem to be the best organic acids for the decontamination of food products (43).

To provide microbial safety, fruit and vegetables are passed through some processing steps, such as cleaning, trimming, peeling, coring, slicing, shredding, washing, and sanitizing. The objective of the washing and sanitizing steps is to remove soil and pesticide residues, reduce the microbial load, and lower the temperature of the product $(9,47)$. Chlorine-based agents often are used to sanitize the surfaces of products and to reduce microbial populations (20). These procedures reduce the initial microbiological load, thus reducing the rate of subsequent spoilage due to the presence of microbes and minimizing the populations of potential pathogens $(24,52)$. Chlorine dioxide $\left(\mathrm{ClO}_{2}\right)$ is a strong oxidizing and sanitizing agent that can be used in aqueous or gaseous form to sanitize foods. $\mathrm{ClO}_{2}$ is gaining importance for maintaining the shelf life of fresh produce. The U.S. Food and Drug Administration (55) has allowed the use of aqueous $\mathrm{ClO}_{2}$ during the washing of fruits and vegetables at a residual level of $3 \mathrm{ppm}$. After the washing step, the fruits and vegetables should be rinsed with potable water (52). A maximum $\mathrm{ClO}_{2}$ concentration of $200 \mathrm{ppm}$ should be used for sanitizing processing equipment (23).

Vacuum packaging is a common packaging method in the food industry. The product is placed in a pack that has low oxygen permeability, the air is evacuated, and the package is sealed. Because it is not possible to evacuate all of the air ( 0.3 to $3 \%$ may remain after sealing), the gaseous atmosphere of the vacuum package is likely to change during storage (because of microbial and product metabolism and gas permeation), so the atmosphere in the package may be different from the original atmosphere (32).

The objective of this study was to evaluate the effect of different concentrations of $\mathrm{NaCl}$, organic acids (acetic and lactic acid), and commercial disinfectant $\left(\mathrm{ClO}_{2}\right)$ on the microbiological, physicochemical, and organoleptic profiles of Gemlik and Edincik natural black olives during a drysalting process and the stability of these olives during storage at $4^{\circ} \mathrm{C}$. The results could be useful for the table olive industry to modify the existing processing scheme to obtain a final product that has lower sodium concentrations but maintains its traditional properties.

\section{MATERIALS AND METHODS}

Raw material and sample treatment. In December 2012, black olives (cultivars Gemlik and Edincik) were harvested in Erdek, Turkey and transported to the laboratory within $24 \mathrm{~h}$. On arrival, the fruit was hand selected and separated into six lots of equal weight (approximately $50 \mathrm{~kg}$ each). For five lots, each lot of olives was immersed separately for $10 \mathrm{~min}$ in 100 liters of water containing 1 or $2 \%$ lactic acid (100366.2500, Merck, Darmstadt, Germany), 1 or $2 \%$ acetic acid (100063.2511, Merck), or $10 \mathrm{ppm}$ of commercial disinfectant (DK-DOX $0.3 \%$ liquid $\mathrm{ClO}_{2}$, Link Chemie AG, Dürrwiesen, Germany). The sixth lot (control) was dipped thoroughly in only distilled water, and a separator was used to keep the olives fully immersed. All olive lots were then dipped thoroughly in distilled water (olive:distilled water, 1:2, wt/vol, for $10 \mathrm{~min}$ ) and left to dry at room temperature for $30 \mathrm{~min}$. Olive samples of approximately $18 \mathrm{~kg}$ (from each of the lots prewashed with dipping solutions and distilled water) were each packed in a 30 -liter polyvinyl chloride container with uniformly dispersed coarse salt at different $\mathrm{NaCl}$ concentrations $(2.5,5.0$, and $10.0 \%$ per $18 \mathrm{~kg}$ of olives). To prevent fungal growth, the surface of the fruit was covered with a 2- to 3-cm layer of salt. During the process, the containers were kept at ambient temperature $(20 \pm$ $1^{\circ} \mathrm{C}$ ). Water and other solutes were drained through a hole at the bottom of the drum and collected during the dry-salting process (every 20 days). At the end of the dry-salting process ( 60 days), the six lots were each dipped separately in distilled water for $10 \mathrm{~min}$ to remove the excess $\mathrm{NaCl}$ and left to dry at room temperature for $20 \mathrm{~min}$ before packaging (18).

Packaging. After the dry-salting process, olives were vacuum packaged (VC 999/K12NA packing machine, Verpackungssysteme AG, Herisau, Switzerland) in FMXBK polyamide-polyethylene film $\left(\mathrm{PO}_{2}=15 \mathrm{~cm}^{3} / \mathrm{m}^{2} / 24 \mathrm{~h}\right.$ at $23^{\circ} \mathrm{C}$ and $75 \%$ relative humidity; Flexopack S.A. Plastics Industry, Koropi, Greece). All of the samples, which had been dipped in different washing solutions (Table 1) or distilled water (control), were packaged separately and stored at $4 \pm 1^{\circ} \mathrm{C}$ (refrigerator temperature) for 7 months.

Physicochemical analysis. All $\mathrm{pH}$ values were determined with a microprocessor $\mathrm{pH}$ meter (HI 221, Hanna Instruments, Woonsocket, RI). The moisture and salt contents of the olive flesh were determined according to the method of Panagou et al. (39) and by the titrimetric method of the International Olive Council (31), respectively. All physicochemical analyses were conducted in triplicate.

Microbiological analysis. The level of microorganisms was determined for fresh olives and each type of treated sample. For each analysis, $25 \mathrm{~g}$ of each sample was weighed aseptically, placed in $225 \mathrm{ml}$ of a sterile maximum recovery dilution solution ( $1 \mathrm{~g} / \mathrm{liter}$ peptone plus $8.5 \mathrm{~g} /$ liter saline), homogenized in a stomacher (Masticator, IUL Instruments, Barcelona, Spain) for $60 \mathrm{~s}$ at room temperature $\left(20 \pm 1^{\circ} \mathrm{C}\right)$, and used for the microbiological analyses. Decimal dilutions in the same maximum recovery dilution solution were prepared, and duplicates of 1 or $0.1 \mathrm{ml}$ of at least three appropriate dilutions were pour plated or spread plated on the following agar media: plate count agar (CMO325, Oxoid, Basingstoke, UK) for aerobic microorganisms (AM), incubated at $25^{\circ} \mathrm{C}$ for $48 \mathrm{~h}$; de Man Rogosa Sharpe medium (CM0361 supplemented with SR0222C, Oxoid) for lactic acid 
TABLE 1. Abbreviations used for dry-salted olive samples

\begin{tabular}{|c|c|c|c|c|}
\hline Run & Olive variety & Abbreviation & Washing solution concn & Salt concn $(\%)$ \\
\hline 1 & Gemlik & GCS1 & Control & 2.5 \\
\hline 2 & Edincik & ECS1 & Control & 2.5 \\
\hline 3 & Gemlik & GCS2 & Control & 5.0 \\
\hline 4 & Edincik & ECS2 & Control & 5.0 \\
\hline 5 & Gemlik & GCS3 & Control & 10.0 \\
\hline 6 & Edincik & ECS3 & Control & 10.0 \\
\hline 7 & Gemlik & GL1S1 & $1 \%$ lactic acid & 2.5 \\
\hline 8 & Edincik & EL1S1 & $1 \%$ lactic acid & 2.5 \\
\hline 9 & Gemlik & GL1S2 & $1 \%$ lactic acid & 5.0 \\
\hline 10 & Edincik & EL1S2 & $1 \%$ lactic acid & 5.0 \\
\hline 11 & Gemlik & GL1S3 & $1 \%$ lactic acid & 10.0 \\
\hline 12 & Edincik & EL1S3 & $1 \%$ lactic acid & 10.0 \\
\hline 13 & Gemlik & GL2S1 & $2 \%$ lactic acid & 2.5 \\
\hline 14 & Edincik & EL2S1 & $2 \%$ lactic acid & 2.5 \\
\hline 15 & Gemlik & GL2S2 & $2 \%$ lactic acid & 5.0 \\
\hline 16 & Edincik & EL2S2 & $2 \%$ lactic acid & 5.0 \\
\hline 17 & Gemlik & GL2S3 & $2 \%$ lactic acid & 10.0 \\
\hline 18 & Edincik & EL2S3 & $2 \%$ lactic acid & 10.0 \\
\hline 19 & Gemlik & GA1S1 & $1 \%$ acetic acid & 2.5 \\
\hline 20 & Edincik & EA1S1 & $1 \%$ acetic acid & 2.5 \\
\hline 21 & Gemlik & GA1S2 & $1 \%$ acetic acid & 5.0 \\
\hline 22 & Edincik & EA1S2 & $1 \%$ acetic acid & 5.0 \\
\hline 23 & Gemlik & GA1S3 & $1 \%$ acetic acid & 10.0 \\
\hline 24 & Edincik & EA1S3 & $1 \%$ acetic acid & 10.0 \\
\hline 25 & Gemlik & GA2S1 & $2 \%$ acetic acid & 2.5 \\
\hline 26 & Edincik & EA2S1 & $2 \%$ acetic acid & 2.5 \\
\hline 27 & Gemlik & GA2S2 & $2 \%$ acetic acid & 5.0 \\
\hline 28 & Edincik & EA2S2 & $2 \%$ acetic acid & 5.0 \\
\hline 29 & Gemlik & GA2S3 & $2 \%$ acetic acid & 10.0 \\
\hline 30 & Edincik & EA2S3 & $2 \%$ acetic acid & 10.0 \\
\hline 31 & Gemlik & GDS1 & Chlorine dioxide & 2.5 \\
\hline 32 & Edincik & EDS1 & Chlorine dioxide & 2.5 \\
\hline 33 & Gemlik & GDS2 & Chlorine dioxide & 5.0 \\
\hline 34 & Edincik & EDS2 & Chlorine dioxide & 5.0 \\
\hline 35 & Gemlik & GDS3 & Chlorine dioxide & 10.0 \\
\hline 36 & Edincik & EDS3 & Chlorine dioxide & 10.0 \\
\hline
\end{tabular}

bacteria ( $\mathrm{LAB})$, overlaid with the same medium and incubated at $30^{\circ} \mathrm{C}$ for $48 \mathrm{~h}$; rose Bengal chloramphenicol agar (CM 549 supplemented with SR78, Oxoid) for yeasts and molds (YM), incubated at $25^{\circ} \mathrm{C}$ for $72 \mathrm{~h}$ or 5 days; cetrimide-fucidincephalorodine medium (CM 559 supplemented with SR 103, Oxoid) for Pseudomonas counts, incubated at $25^{\circ} \mathrm{C}$ for $48 \mathrm{~h}$; and violet red bile glucose agar (1.10275.0500, Merck) for Enterobacteriaceae counts, incubated at $37^{\circ} \mathrm{C}$ for $24 \mathrm{~h}$. The results for viable populations of microorganisms were expressed as log CFU per gram of olive pulp in fresh and packaged samples $(18,19)$. Experiments were conducted twice on different occasions with different dry-salted olives. Analyses were run in triplicate for each replicate $(N=3 \times 2)$. The limits of detection were calculated by the International Union of Pure and Applied Chemistry method (35) for each microbiological analysis and were approximately 10 $\mathrm{CFU} / \mathrm{g}$ for the media used.

Sensory evaluation. Sensory evaluation was conducted with 36 untrained assessors ( 16 women and 20 men) 24 to 45 years of age. The assessors indicated their sensory evaluation for each attribute using a 9-point hedonic scale of 1 to 9 (where 1 is "dislike extremely," 5 is "neither like nor dislike," and 9 is "like extremely"). Samples were identified by random numbers and presented in individual trays to the assessors. The main quality attributes (Table 2) were divided into four groups corresponding to (i) color (black, black-brown, and brown), (ii) taste (salty, bitter, rancid, and off-flavor), (iii) texture and flesh stone (softness, pitflesh detachment), and (iv) overall eating quality. All samples were tested at room temperature under normal daylight conditions. To reduce the likelihood of carryover, 2- and 10-min intervals were allowed between each sample and between each set of three samples, respectively. Each assessor was provided with filtered water and unsalted crackers and asked to cleanse her or his palate between tastings. Sensory attributes and their definitions were adapted from those of Değirmencioğlu et al. (19).

Statistical analysis. The data were analyzed with the SPSS statistical package (version 16.0, SPSS, IBM, Chicago, IL). These analyses were conducted in triplicate for each sample. Viable populations of microorganisms were expressed statistically. The general linear model (repeated measures) and multiple comparison analyses were performed to estimate the significance $(P<0.05)$ of the effects of washing treatments and salt concentrations on the microbiological quality and the sensory data for each attribute. The least significant difference test was used to determine differences between olives treated with the various washing solutions and salt 
TABLE 2. Scores assigned for the evaluation of olive sensory attributes

\begin{tabular}{lll}
\hline \multirow{2}{*}{ Attribute } & \multicolumn{2}{c}{ Score descriptions } \\
\cline { 2 - 3 } & \multicolumn{1}{c}{ Minimum (1) } & \multicolumn{1}{c}{ Maximum (9) } \\
\hline Flesh color & Brown & Black \\
Flesh saltiness & Salty & Suitable \\
Flesh bitterness & Bitter & Not bitter \\
Flesh rancidity & Rancid & Not rancid \\
Flesh off-flavor & Dislike & Like \\
Flesh hardness & Stiff & Hard \\
Pit-flesh detachment & Easy & Hard \\
Overall eating & & \\
\multicolumn{1}{c}{ quality } & Dislike extremely & Like extremely \\
\hline
\end{tabular}

concentrations. The mean values were submitted to a multiple comparison test using the least significant difference procedure that allows the attributes that differentiate the samples to be determined.

\section{RESULTS AND DISCUSSION}

Microbiological changes in dry-salted olives. Olives are one of the major agricultural products of Turkey. The most common two Turkish olive varieties, Gemlik and Edincik (or Edincik-Su), constitute the majority of the olive production in the region of the Sea of Marmara (northwestern Turkey) and the Aegean and are best suited for processing natural black olives. Gemlik is the common variety used for table olives and olive oil because of its thin skin, small stone, low acidity, high protein and sugar content, high fruit and oil yield, early maturation, low periodicity, and organoleptic qualities highly valued by consumers $(7,13,48)$. The Edincik variety has large spherical fruits, a very small stone, low oil content, high moisture and sugar content, and firm flesh. The high moisture content gives the variety its name. Particular care must be taken during harvesting and processing of this variety because of its soft texture and very delicate skin and pulp $(13,54)$. In this study, the initial populations of AM, $\mathrm{LAB}$, and $\mathrm{YM}$ of the olive samples were 5.38, 4.41, and $2.85 \log$ CFU/g for Gemlik olives and 5.41, 4.41, and 2.80 $\log \mathrm{CFU} / \mathrm{g}$ for Edincik olives, respectively. After being packed in $\mathrm{NaCl}$ for 60 days, the counts of $\mathrm{AM}, \mathrm{LAB}$, and YM of control samples decreased to 3.26, 3.14, and $2.76 \log$ $\mathrm{CFU} / \mathrm{g}$ for Gemlik olives all salt concentrations and 3.26, 2.40, and $2.38 \log \mathrm{CFU} / \mathrm{g}$ for Edincik olives of all salt concentrations, respectively. The data from the samples of all three $\mathrm{NaCl}$ concentrations $(2.5,5.0$, and $10.0 \%)$ tested revealed that washing with distilled water (for $10 \mathrm{~min}$ ) did not control the increases in $\mathrm{AM}$ and $\mathrm{LAB}$ counts as well as did washing with organic acids or $\mathrm{ClO}_{2}$ before the drysalting process. In raw olives after harvest, AM, LAB, and YM counts were detected at low levels. This finding was expected because the olives had been harvested and selected by hand, resulting in minimal damage. Similar microbiological results were reported in a survey of Moroccan drysalted olives, in which the most common microbiota were YM (8). In the present study, the increase in AM counts in the Gemlik samples was not controlled in all washing solutions during the dry-salting process and was reduced by higher $\mathrm{NaCl}$ concentrations; however, in the Edincik samples, AM counts were controlled by washing with $2.0 \%$ acetic acid (2.11 to $2.26 \log \mathrm{CFU} / \mathrm{g}$ ) or $\mathrm{ClO}_{2}$ (2.06 to $2.08 \log \mathrm{CFU} / \mathrm{g}$ ) solutions at the end of the day 6 , compared with AM counts of $2.20 \log \mathrm{CFU} / \mathrm{g}$ (2.0\% acetic acid) and $2.11 \log \mathrm{CFU} / \mathrm{g}\left(\mathrm{ClO}_{2}\right.$ solutions $)$ at the day 0 of dry salting.

In this study, LAB counts in control samples increased in Gemlik olives from $3.14 \log$ CFU/g initially to 3.36 to $3.54 \log \mathrm{CFU} / \mathrm{g}$ and in Edincik olives from $2.40 \mathrm{log}$ CFU/g initially to 3.25 to $3.34 \log \mathrm{CFU} / \mathrm{g}$ for all salt concentrations; increases in salt concentrations did not make a significant difference $(P>0.05)$. The effect of environmental stress factors on developing resistance of microorganisms to antimicrobials is of great importance. Therefore, the significant increase $(P<0.05)$ in LAB counts from $<1$ to $1.00 \log \mathrm{CFU} / \mathrm{g}$ to 2.53 to $3.08 \log \mathrm{CFU} / \mathrm{g}$ and $2.88-3.14$ $\log \mathrm{CFU} / \mathrm{g}$ in Gemlik olives and from $1.00 \mathrm{log} \mathrm{CFU} / \mathrm{g}$ to 2.10 to $2.27 \log \mathrm{CFU} / \mathrm{g}$ and 2.24 to $3.14 \mathrm{log} \mathrm{CFU} / \mathrm{g}$ in Edincik olives washed in lactic and acetic acid solutions (with $2.5 \%$ salt), respectively, during the dry-salting process was affected by microbial, intrinsic, and extrinsic factors such as resistance of strains, growth rate and phase, interaction with other microorganisms, cellular composition and status (injury), water activity, and $\mathrm{pH}$ and created a hurdle effect combined with the use of antimicrobial agents. No increase in LAB counts were found in the Edincik samples at 5.0 and $10.0 \% \mathrm{NaCl}$, with the exception of the control samples. All washing solutions were more effective than distilled water in Edincik olives than in Gemlik olives for restricting the growth of $\mathrm{LAB}$, depending on the salt concentration.

Several studies have focused on the detection of yeasts that adhere to the surface of olives. Arroyo-López et al. (5) reported the presence of yeasts among the microbiota found on the surface of fresh mature olives, and the yeast species found depended on the maturation degree of the olives. However, yeast counts on the surface of fresh olives are generally low $(<1 \log \mathrm{CFU} / \mathrm{g}$ ), as was reported by ArroyoLópez et al. (4) for Manzanilla-Aloreña olives during three consecutive seasons. The before and after washing with distilled water, YM counts were 2.85 and $2.76 \mathrm{log}$ CFU/g (Gemlik olives) and 2.80 and $2.38 \mathrm{log} \mathrm{CFU} / \mathrm{g}$ (Edincik olives), respectively. After $10 \mathrm{~min}$ of washing with lactic and acetic acid solutions, YM counts were 2.49 to 2.58 and 2.49 to $2.57 \log$ CFU/g (Gemlik olives) and 1.04 to 1.23 and 1.11 to $1.23 \mathrm{log} \mathrm{CFU} / \mathrm{g}$ (Edincik olives), respectively, whereas $\mathrm{YM}$ counts were $<1 \mathrm{log} \mathrm{CFU} / \mathrm{g}$ in both olive cultivars washed with $\mathrm{ClO}_{2}$. During the dry-salting process, the YM counts of Gemlik olives increased slightly for the samples with $2.5 \%$ salt concentration that were washed in organic acid solutions. Washing with distilled water (control samples, Gemlik olives) was not effective for controlling the growth of YM at all three salt concentrations for 60 days. The various lactic and acetic acid solutions and higher $\mathrm{NaCl}$ concentrations were not effective for preventing the increase in YM counts in Gemlik olives $(P>0.05)$, but washing in 1 and $2 \%$ acetic and lactic acid solutions for 10 min restricted the increase of $\mathrm{YM}$ counts at 5.0 and $10.0 \% \mathrm{NaCl}$ 
Gemlik cv., AM count, $2.5 \%$ salt

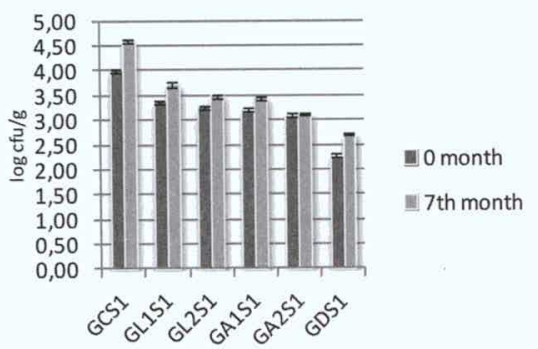

Gemlik cv., AM count, $5.0 \%$ salt

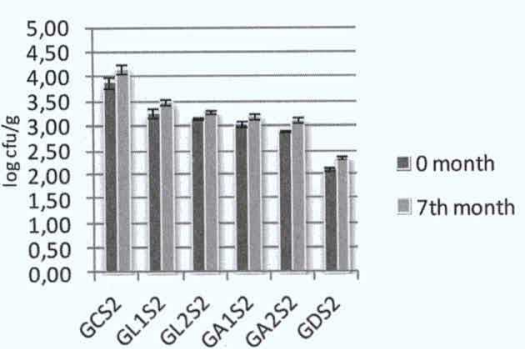

Gemlik cv., AM count, $10.0 \%$ salt

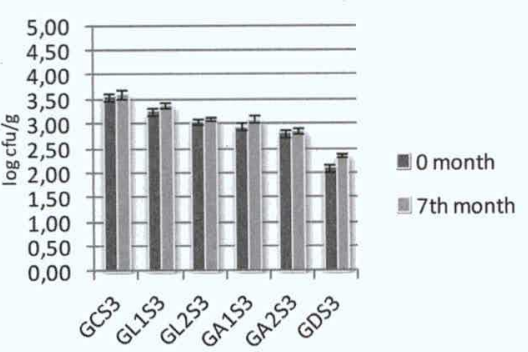

Edincik cv., AM count, $2.5 \%$ salt

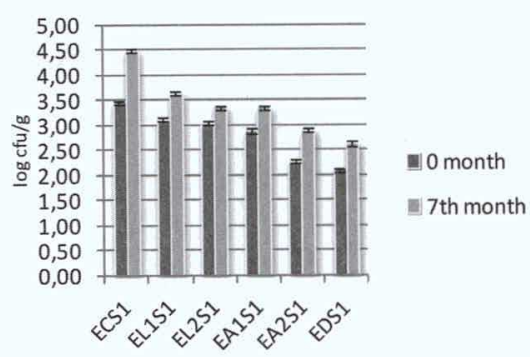

Edincik cv., AM count, $5.0 \%$ salt

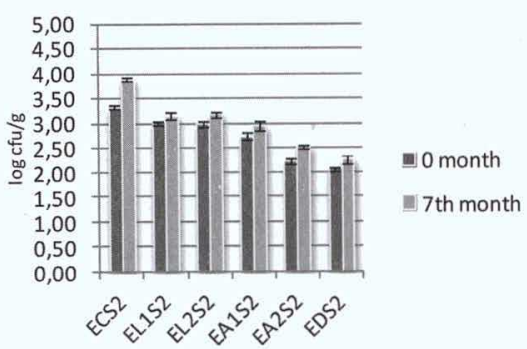

Edincik cv., AM count, $10.0 \%$ salt

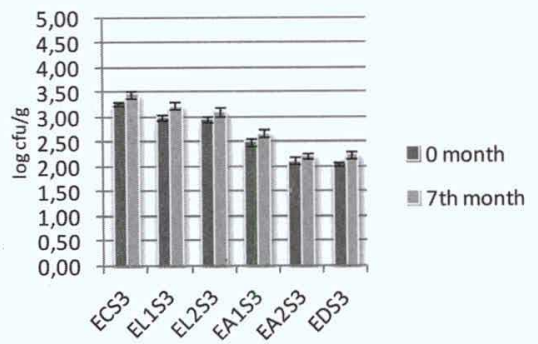

FIGURE 1. Aerobic microorganism (AM) counts in dry-salted olives before and after storage at $4^{\circ} \mathrm{C}$. Data points are means of repeated measurements obtained from two replicates of dry-salted olive samples. The corresponding error bars represent the standard deviations. G, Gemlik olives; E, Edincik olives; $C$, control; L, lactic acid; A, acetic acid; $D$, disinfectant; $S 1,2.5 \% \mathrm{NaCl}$ concentration; $\mathrm{S} 2,5.0 \% \mathrm{NaCl}$ concentration; $\mathrm{S3}, 10.0 \% \mathrm{NaCl}$ concentration. concentrations in Edincik olives. Organic acids may affect the integrity of the microbial cell membrane or cell macromolecules or interfere with nutrient transport and energy metabolism, causing a bactericidal effect. An inhibition effect also can be created with a combination of organic acids and other preservation methods (42). Spoilage bacteria on fresh vegetables were inhibited by salt during production of sauerkraut, olives, and various pickles, whereas the fermenting LAB thrived (21). The preservative properties of $\mathrm{NaCl}$ are based on the direct toxicity of $\mathrm{Cl}^{-}$, removal of oxygen from the medium, sensitization of the organisms to $\mathrm{CO}_{2}$, and interference with the rapid action of proteolytic enzymes (50). In the present study, the $\mathrm{NaCl}$ concentrations in the olives determined which microorganisms would be dominant during the dry-salting process. The YM counts in Gemlik olives that were dry-salted after being washed in distilled water or organic acid solutions were not significantly different $(P>0.05)$ regardless of the salt concentrations, and washing in $\mathrm{ClO}_{2}$ solution (10 ppm) for $10 \mathrm{~min}$ was more effective than washing in the other solutions for both reducing initial LAB and YM counts and controlling the growth of LAB and YM during the debittering process during the 60-day study.

Microbiological changes during storage of drysalted olives. The effects of $\mathrm{NaCl}$ concentration $(2.5,5.0$, and $10.0 \%$ ) on changes in AM, LAB, and YM counts of dry-salted olives during storage are presented in Figures 1 through 3 . The use of vacuum packaging for the shelf life of the fruit did not effectively control the increase in AM and LAB counts in the control samples that had not been washed in any chemical solutions (see Fig. 1) or dipped in the distilled water after the initial dry-salting process. The increases in $\mathrm{AM}$ and $\mathrm{LAB}$ counts were from 3.45 to $3.99 \mathrm{log}$ CFU/g initially to 4.48 to $4.59 \mathrm{log} \mathrm{CFU} / \mathrm{g}$ and from 3.34 to $3.54 \log \mathrm{CFU} / \mathrm{g}$ initially to 3.65 to $3.68 \log \mathrm{CFU} / \mathrm{g}$, respectively, during the shelf life of 7 months at $4{ }^{\circ} \mathrm{C}$ (Figs. 1 and 2). The AM and LAB counts were not affected $(P>0.05)$ in the samples that had not been dipped in the $\mathrm{ClO}_{2}$ solution. No significant differences in AM and LAB counts were found for either olive cultivar between the storage periods $(P>0.05)$.

Panagou (36) found that the initial populations of AM and LAB changed only slightly and remained at about 7 log $\mathrm{CFU} / \mathrm{ml}$ irrespective of packaging type (air, vacuum, or modified atmosphere) when a temperature of $20^{\circ} \mathrm{C}$ was maintained during the shelf life. Değirmencioğlu (18) found that the AM count remained stable until month 3 and then increased until the month 7 of shelf life and that vacuum treatment restricted the increase of LAB. In our study, the vacuum packaging did not significantly restrict the increase in LAB counts at low salt concentrations resulting from the differences of washing solutions, except for those olive washed in $\mathrm{ClO}_{2}$. 
FIGURE 2. Lactic acid bacteria (LAB) counts in dry-salted olives before and after storage at $4^{\circ} \mathrm{C}$. Data points are means of repeated measurements obtained from two replicates of dry-salted olive samples. The corresponding error bars represent the standard deviations. G, Gemlik olives; $E$, Edincik olives; $C$, control; $L$, lactic acid; A, acetic acid; $D$, disinfectant; $S 1,2.5 \% \mathrm{NaCl}$ concentration; $\mathrm{S} 2,5.0 \% \mathrm{NaCl}$ concentration; $\mathrm{S} 3,10.0 \% \mathrm{NaCl}$ concentration.
Gemlik cv., LAB count, $2.5 \%$ salt

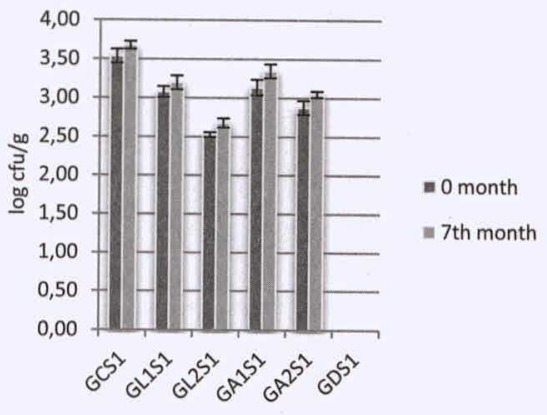

Gemlik cv., LAB count, $5.0 \%$ salt



Gemlik cv., LAB count, $10.0 \%$ salt

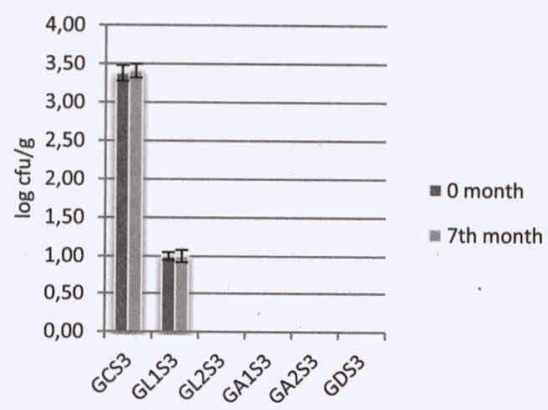

Edincik Cv., LAB cont, $2.5 \%$ salt

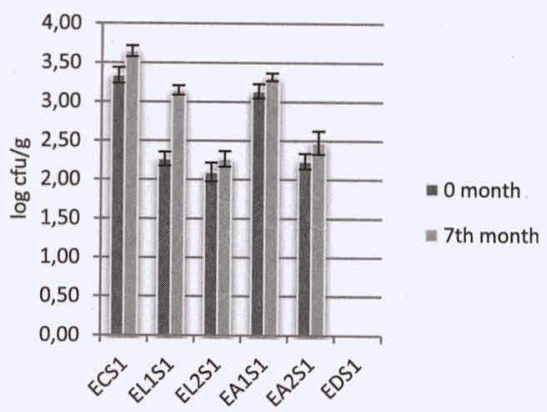

Edincik cv., LAB count, $5.0 \%$ salt

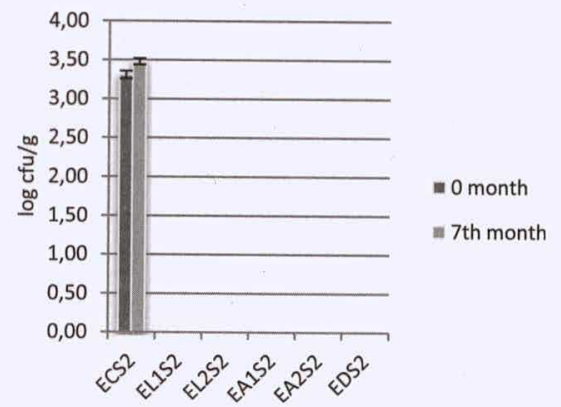

Edincik cv., LAB count, $10.0 \%$ salt

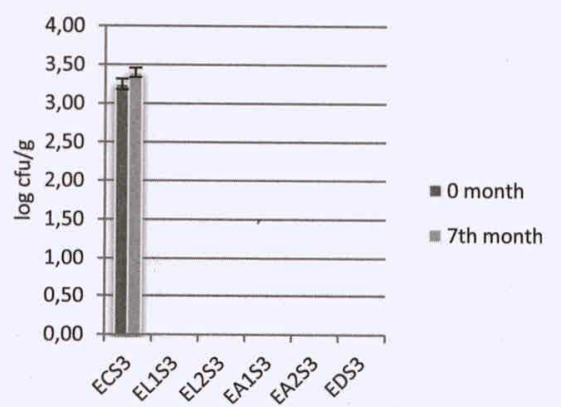

During storage, dry-salted olives are vacuum packed without brine in polyamide-polyethylene film. Yeasts and fungi are potential spoilage microorganisms because of their ability to grow in low water activity environments. Spoilage during storage also may occur when olives are not dry enough or not sufficiently salted. The growth of these organisms, mainly fungi, may negatively affect both the nutritional and the aesthetic value of the product. By the end of the shelf life studied, the total YM population increased from 3.02 to $3.25 \log \mathrm{CFU} / \mathrm{g}$ initially to 3.60 to $3.65 \mathrm{log}$ $\mathrm{CFU} / \mathrm{g}$ in control samples at $2.5 \%$ salt concentration and $4^{\circ} \mathrm{C}$. No significant differences were found throughout the storage period $(P>0.05)$. Acetic acid solutions (1 and $2 \%)$ were more effective for controlling YM counts than were the other solutions, depending on the salt concentration, during the storage period (Fig. 3). The exception were the samples washed with $\mathrm{ClO}_{2}$, which had YM counts of 2.85 and $<1 \log$ CFU/g (Gemlik olives) and 2.80 and $<1 \log$ $\mathrm{CFU} / \mathrm{g}$ (Edincik olives) before and after washing, respectively. YM counts in these samples did not increase throughout the dry-salting and storage periods, in contrast to samples that were dipped only in distilled water and stored at $4^{\circ} \mathrm{C}$. Therefore, the $\mathrm{ClO}_{2}$ wash solution effectively inhibited or restricted YM growth in dry-salted samples at all $\mathrm{NaCl}$ concentrations. Although microorganisms entered the olives through cracks in the fruit, the $\mathrm{ClO}_{2}$ solution was able to sufficiently penetrate these areas. Dry-salted olives have low water activity and high $\mathrm{NaCl}$ content, which allows only salt-tolerant yeasts to grow (53). Panagou et al. (39) determined that yeast populations declined steadily throughout the storage period at $4^{\circ} \mathrm{C}$. Panagou (36) also found that yeast populations in vacuum-packed olives started to decline when the experiments began, and the lowest count $(3 \log \mathrm{CFU} / \mathrm{g}$ ) was reached after 150 days of storage at $20^{\circ} \mathrm{C}$. Değirmencioğlu (18) established that chlorine treatment and modified atmosphere packaging $\left(35 \% \mathrm{CO}_{2}\right.$ and $65 \% \mathrm{~N}_{2}$ ) to suppressed $\mathrm{YM}$ growth better than did vacuum packaging (1.22 log CFU/g, 6 months at $4^{\circ} \mathrm{C}$ ). By comparison, in the present study, the YM count (Fig. 3) was lower at the end of the storage period than those reported by Değirmencioğlu (18), Panagou et al. (39), and Panagou (36). 
Gemlik cv., YM count, $2.5 \%$ salt

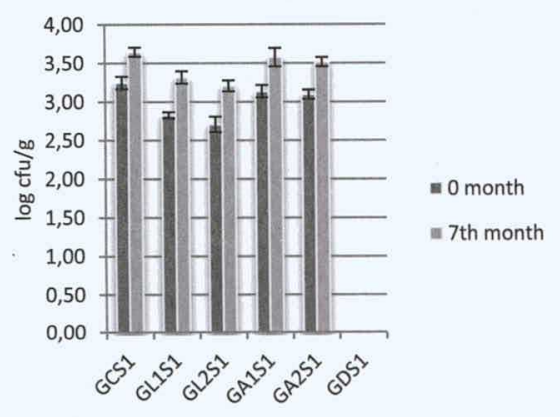

Gemlik cv., YM count, $5.0 \%$ salt

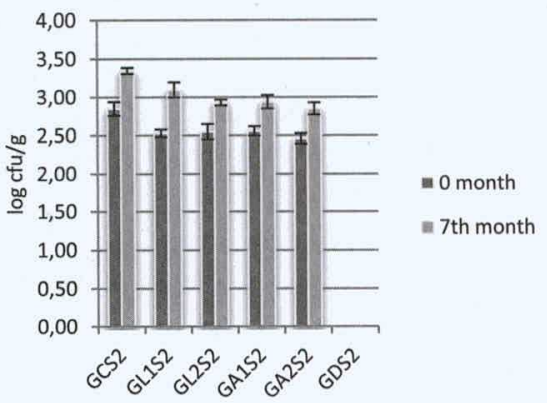

Gemlik cv., YM count, $10.0 \%$ salt

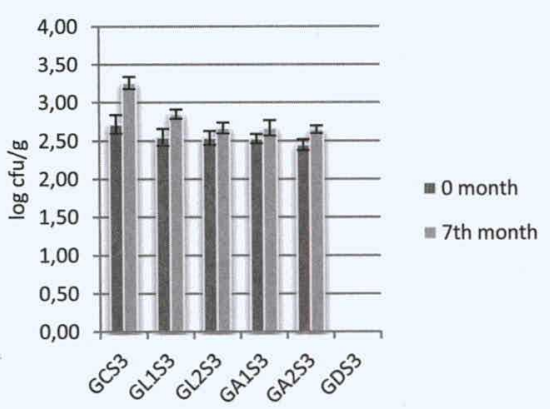

Edincik cv., YM count, $2.5 \%$ salt

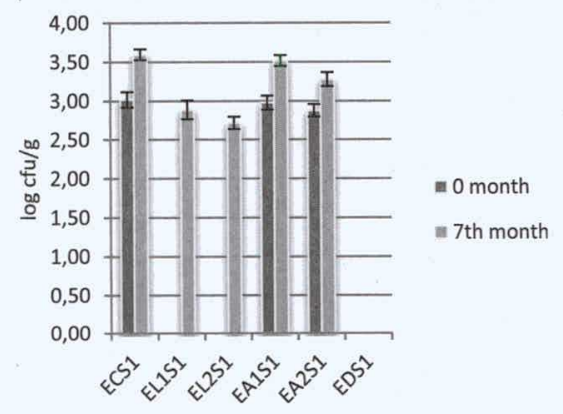

Edincik cv., YM count, $5.0 \%$ salt

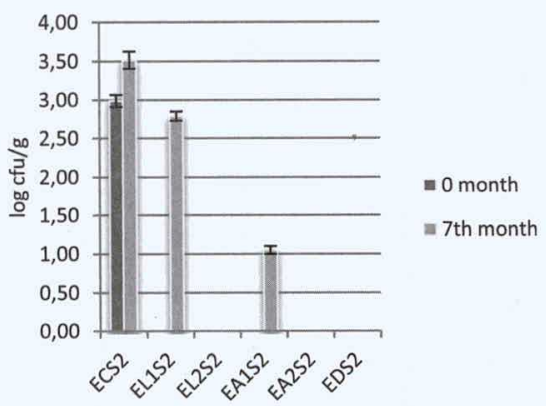

Edincik cv., YM count, $10.0 \%$ salt

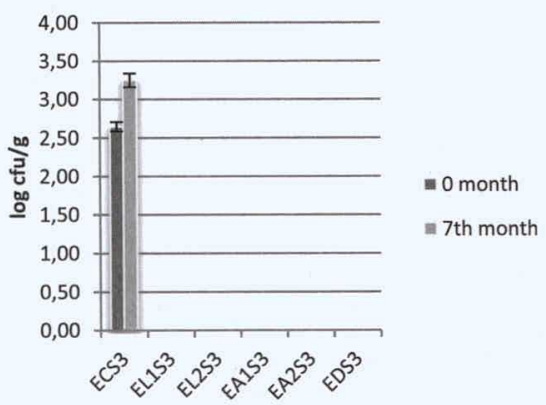

FIGURE 3. Yeast and mold (YM) counts in dry-salted olives before and after storage at $4{ }^{\circ} \mathrm{C}$. Data points are means of repeated measurements obtained from two replicates of dry-salted olive samples. The corresponding error bars represent the standard deviations. $G$, Gemlik olives; $E$, Edincik olives; $C$, control; $L$, lactic acid; A, acetic acid; $D$, disinfectant; $S 1,2.5 \% \mathrm{NaCl}$ concentration; $S 2,5.0 \% \mathrm{NaCl}$ concentration; $\mathrm{S} 3,10.0 \% \mathrm{NaCl}$ concentration.
Panagou et al. (39) isolated some salt-tolerant yeast strains that grew in the presence of solutions of $15 \mathrm{~g}$ of $\mathrm{NaCl}$ per $100 \mathrm{~g}$ of water. The sample of dry-salted olives contained 2.1 to $9.7 \% \mathrm{NaCl}$. The results indicated that even when salt-tolerant yeast strains are present, the combination of $\mathrm{ClO}_{2}(10 \mathrm{ppm})$ wash and vacuum packaging would effectively control YM growth on samples stored at $4^{\circ} \mathrm{C}$. In the present study, we also evaluated the antimicrobial effectiveness of aqueous $\mathrm{ClO}_{2}$ plus vacuum packaging, which is a more useful and less expensive olive packaging method for small companies compared with modified atmosphere packaging. The effect of vacuum packaging on microbial growth was impacted significantly by temperature and by $\mathrm{ClO}_{2}$ washing.

Low temperature is an important factor for maintaining the microbial quality of food products. Low temperature during the shelf life of dry-salted olives is essential to control microbial growth and maintain sensory qualities. Betts et al. (11) suggested a synergistic effect between $\mathrm{pH}$ and $\mathrm{NaCl}$ at low temperatures that could be used for assessing the spoilage potential of new and existing product formulations. Lowering the storage temperature and the use of washing solutions were more important factors than vacuum packaging for reducing microbial counts. Hurtado et al. (30) reported that higher oxygen concentrations more effectively retarded YM growth on the surface of control samples than did higher salinity. However, storage at a relatively low temperature is also essential for the successful processing of dry-salted olives. The conditions of lowtemperature storage, vacuum packaging, and various salt concentrations in the present study restricted YM growth throughout the 7 months of shelf life. Consequently, the combination of treatment of olives with dry salting and a $\mathrm{ClO}_{2}$ wash has the potential to increase the shelf life by slowing YM growth.

The microbiota of vegetables and fruits is made up largely of Pseudomonas spp., Erwinia herbicola, Flavobacterium, Xanthomonas, Enterobacter agglomerans, and various $\mathrm{YM}$ and $\operatorname{LAB}(15,40,41)$. Pseudomonas is not harmful to humans but is normally predominant and account for 50 to $90 \%$ of the microbial population on many vegetables (58). The levels of enteric bacteria on the surface 
Gemlik cv., $2.5 \%$ salt

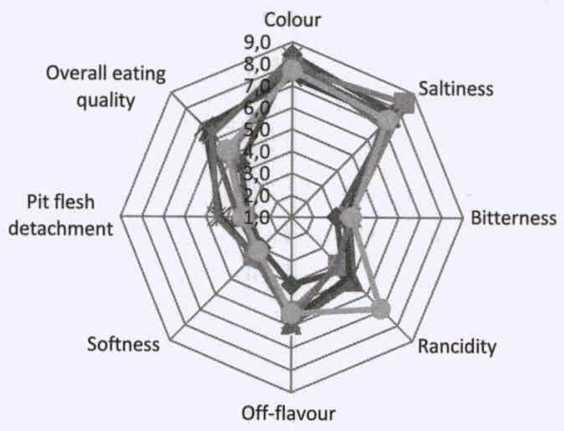

$\longrightarrow \mathrm{GCS} 1 \longrightarrow \mathrm{GL} 1 \mathrm{S1} \rightleftharpoons \mathrm{GL2S1} \rightleftharpoons \mathrm{GA1S1} \rightleftharpoons \mathrm{GA2S1} \longrightarrow \mathrm{GDS}$

Gemlik cv., $5.0 \%$ salt

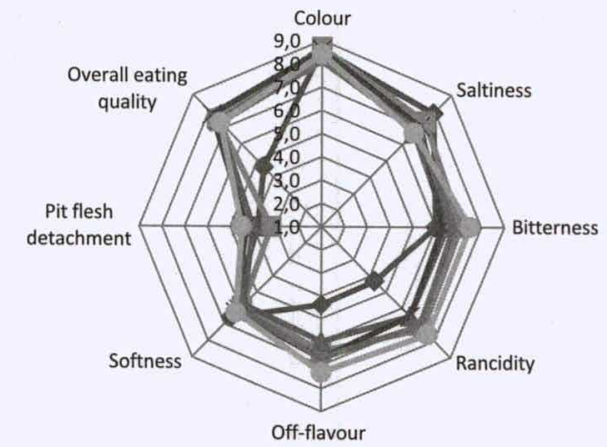

$\longrightarrow \mathrm{GCS} 2 \longrightarrow \mathrm{GL} 1 \mathrm{S2} \longrightarrow \mathrm{GLS2} \longrightarrow \mathrm{GA} 1 \mathrm{S2} \longrightarrow \mathrm{GA} 2 \mathrm{S2} \longrightarrow \mathrm{GDS} 2$

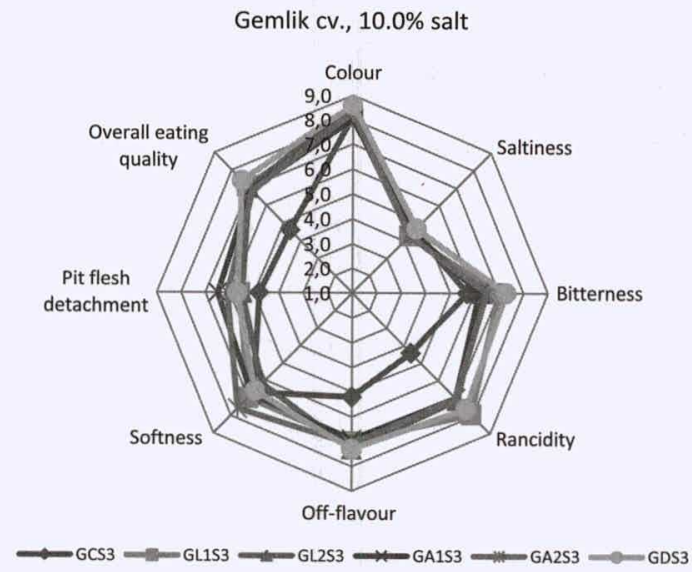

Edincik cv., $2.5 \%$ salt

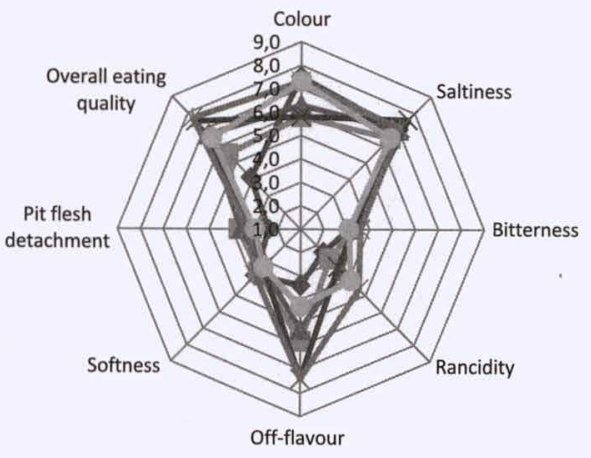

$\longrightarrow$ ECS1 $\rightarrow E L 1 S 1 \longrightarrow$ EL2S1 EA1S1 \#EA2S1 —EDS1

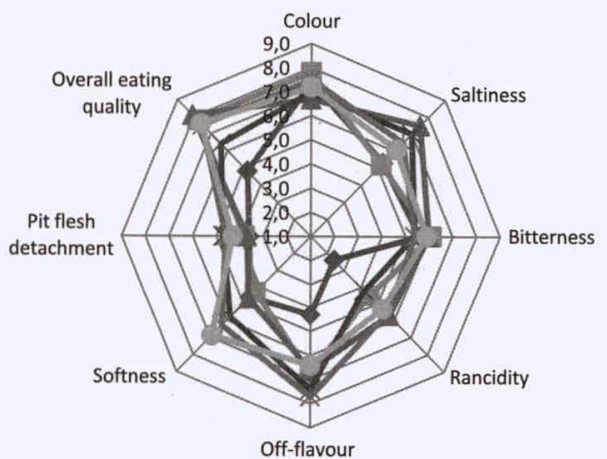

$\longrightarrow \mathrm{ECS2} \longrightarrow \mathrm{EL} 1 \mathrm{S2} \longrightarrow \mathrm{EL2S2} \longrightarrow \mathrm{EA1S2} \longrightarrow \mathrm{EA2S2} \longrightarrow \mathrm{EDS} 2$

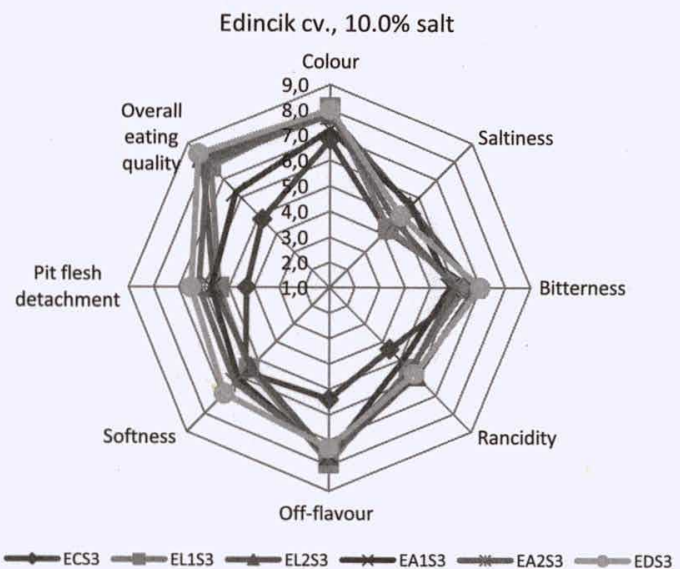

FIGURE 4. Radar plots of mean attributes values showing how the attributes differed among dry-salted olives. G, Gemlik olives; E, Edincik olives; $C$, control; L, lactic acid; A, acetic acid; D, disinfectant; S1, 2.5\% NaCl concentration; S2, 5.0\% NaCl concentration; S3, $10.0 \% \mathrm{NaCl}$ concentration.

of olives could also be influenced by a higher proportion of damaged fruits in a sample, resulting in increased skin permeability in the ripe fruit (56). In the present study, no Enterobacteriaceae or Pseudomonas were detected probably because of the low water activity, high $\mathrm{NaCl}$ concentration, and hand harvesting (resulting in minimal damage to the fruits). Similar microbiological results were reported previously ( 8 ) in a survey of Moroccan dry-salted olives, on which the most prevalent microorganisms were YM. Panagou et al. (39), Panagou (37), and Değirmencioğlu (18) did not detect Enterobacteriaceae and Pseudomonas in the Thassos and Gemlik varieties of dry-salted olives, possibly because of low water activity, high $\mathrm{NaCl}$ concentrations, and relatively low levels of spoilage bacteria.

Physicochemical and sensory changes in vacuumpacked olives. The various washing solutions had no effect on the physicochemical characteristics measured $(\mathrm{pH}$, moisture, and $\mathrm{NaCl}$ concentration), indicating that the olives were stable throughout storage at $4^{\circ} \mathrm{C}$. The same physicochemical characteristics were not affected by the 
treatments, except for the $\mathrm{NaCl}$ concentration of the flesh, which increased as a result of moisture loss. Similar results were obtained in previous experiments reported by Değirmencioğlu et al. (19), Jimenez et al. (33), Panagou et al. (39), and Panagou (36). In the present study, the $\mathrm{NaCl}$ concentrations in dry-salted olives were 2.05 to $9.72 \%$ at the end of the storage period at $4{ }^{\circ} \mathrm{C}$. The moisture content of the vacuum-packaged dry-salted olives decreased from an initial 18.1 to $22.8 \%$ at the beginning of storage to 16.2 to $21.6 \%$ at the end of storage. A corresponding increase in the $\mathrm{NaCl}$ concentration in the flesh occurred, resulting in slight shriveling of the olives.

Changes in the organoleptic characteristics of table olives are easier for the consumer to discern and identify than are the physicochemical and microbiological properties, and the changes also provide a description of the product, which in turn offers a starting point to evaluate product abnormalities, defects, and spoilage (19). The sensory evaluation in this study included color, taste, texture of flesh and stone, and overall eating quality. Figure 4 shows the radar plots of the sensory analysis of dry-salted olives that had been dipped in various solutions, vacuum sealed, and stored at $4{ }^{\circ} \mathrm{C}$ for 7 months. According to the microbiological results, the effectiveness of vacuum packaging followed by $\mathrm{a} \mathrm{ClO}_{2}$ wash used in this study and storage at $4^{\circ} \mathrm{C}$ was greater than the other washing treatments for controlling or inhibiting LAB and YM, which impact sensory attributes.

Microorganisms play an important role in the production of table olives. Diverse microbial groups are involved throughout fermentation and determine the safety, quality, and flavor of the final product (25). Yeasts, which are present in fermented foods and beverages, can be beneficial (technological flora) or detrimental (spoilage flora) (17) and produce ethanol, glycerol, higher alcohols, esters, and other volatile compounds that play an important role in flavor generation and texture maintenance during fermentation and storage $(5,26)$. Most of these compounds are derived from the degradation of polyunsaturated fatty acids through lipoxygenase pathways $(29,44,45)$. However, some polysaccharolytic strains of yeast can become dominant and negatively affect the product quality, causing deterioration of olives through gas pocket formation, softening, etc. $(5,38,57)$. Various investigations have reaffirmed the negative effect of yeasts on the organoleptic characteristics of table olives $(3,5,46)$.

Added $\mathrm{NaCl}$, mainly as a flavoring agent, has a clearly established safety role and substantial effect on the growth or survival of pathogens (10). The exception to this effect is when the samples contain salt-tolerant yeast strains, and the use of a high concentration of $\mathrm{NaCl}$ during fermentation ( $>8 \%$ in the equilibrium) or the dry-salting process could allow the growth of these salt-tolerant yeasts $(18,39,51)$. $\mathrm{NaCl}$ intake is closely related to water loss during dry salting. Therefore, the higher the water loss, the saltier the product becomes. However, $\mathrm{NaCl}$ intake cannot exceed certain limits; otherwise, olives would become organoleptically unacceptable (37). In our study, the flesh of dry-salted olives contained 2.05 to $9.72 \% \mathrm{NaCl}$, and no samples exceeded the specified limits for $\mathrm{NaCl}$ concentration. The $\mathrm{NaCl}$ concentration of dry- salted olives creates the desired level of bitterness. The assessors on the sensory panel in the present study considered the saltiness to be appropriate at 2.5 and $5.0 \%$ and reported that softness and bitterness increased with reduced $\mathrm{NaCl}$ concentrations in both olive varieties. The high saltiness scores obtained with the higher $\mathrm{NaCl}$ concentrations was as a result of enhanced cell wall permeability associated with the soft texture and very delicate skin and pulp. An additional important finding was that the increase in salt diffusion, depending on the salt concentration, had a positive effect $(P$ $<0.05)$ on the softness of the olive flesh. No significant differences $(P>0.05)$ in pit detachment were found between olives washed with various solutions and packaged with the same salt concentrations.

According to the sensory results for vacuum-packed dry-salted olives, Gemlik olives had higher color attribute scores $(P<0.05)$ than did Edincik olives, possibly based on the fresh olive color (gray black). No significant differences $(P>0.05)$ were found between trials of both olive cultivars for scores for rancidity, off-flavors, and overall eating quality (Fig. 4). Traditionally, fermented vegetables are processed using common $\mathrm{NaCl}$ solutions, resulting in $\mathrm{Na}$ as one of the major ingredients in the final product $(25,27)$. In vacuum-packaged samples, the lack of oxygen, the washing solutions used before dry salting, and the primary dry salting with high $\mathrm{NaCl}$ concentrations controlled YM growth; therefore, the assessors gave both rancidity and hardness attributes higher scores.

A combination of preservation treatments for olives is recommended to provide the required level of protection while retaining the organoleptic attributes of the product, such as color, flavor, texture, and nutritional value (14). Treatment with a $\mathrm{ClO}_{2}$ wash $(10 \mathrm{ppm})$ followed by dry salting with $10.0 \%$ salt, vacuum packaging, and storage at $4^{\circ} \mathrm{C}$ was more effective than use of other washing solutions for controlling $\mathrm{LAB}$ counts and suppressing YM growth. However, acetic and lactic acid solutions $(2 \%)$ are useful washing solutions as an alternative to $\mathrm{ClO}_{2}$ when salt concentrations are 5.0 and $10.0 \%$.

\section{REFERENCES}

1. Akbaş, M. Y., and H. Ölmez. 2007. Inactivating of Escherichia coli and Listeria monocytogenes on iceberg lettuce by dip wash treatments with organic acids. Lett. Appl. Microbiol. 44:619-624.

2. Albarracín, W., I. C. Sánchez, R. Grau, and J. M. Barat. 2011. Salt in food processing; usage and reduction: a review. Int. J. Food Sci. Technol. 46:1329-1336.

3. Aponte, M., V. Ventorino, G. Blaiotta, G. Volpe, V. Farina, G. Avellone, C. M. Lanza, and G. Moschetti. 2010. Study of green Sicilian table olive fermentations through microbiological, chemical, and sensory analyses. Food Microbiol. 27:162-170.

4. Arroyo-López, F. N., J. Bautista-Gallego, K. A. Segovia-Bravo, P. García-García, M. C. Durán-Quintana, C. Romero, F. RodríguezGómez, and A. Garrido-Fernández. 2009. Instability profile of fresh packed "seasoned" Manzanilla-Aloreña table olives. LWT Food. Sci. Technol. 42:1629-1639.

5. Arroyo-López, F. N., A. Querol, J. Bautista-Gallego, and A. GarridoFernández. 2008. Role of yeasts in table olive production. Int. J. Food Microbiol. 128:189-196.

6. Arroyo-López, F. N., V. Romero-Gil, J. Bautista-Gallego, F. Rodríguez-Gómez, R. Jiménez-Díaz, P. García-García, A. Querol, and A. Garrido-Fernández. 2012. Yeasts in table olive processing: 
desirable or spoilage microorganisms? Int. J. Food Microbiol. 160: 42-49.

7. Arslan, D. 2012. Physico-chemical characteristics of olive fruits of Turkish varieties from the province of Hatay. Grasas Aceites 63:158166.

8. Asehraou, A., M. Faid, and M. Jana. 1992. Physico-chemical properties and the microflora of Moroccan black table olives. Grasas Aceites 43:130-133

9. Baur, S., R. Klaibe, H. Wei, W. P. Hammes, and R. Carle. 2005. Effect of temperature and chlorination of pre-washing water on shelflife and physiological properties of ready-to-use iceberg lettuce. Innov. Food Sci. Emerg. Technol. 6:171-182.

10. Bautista-Gallego, J., F. N. Arroyo-López, M. C. Durán-Quintana, and A. Garrido-Fernández. 2010. Fermentation profiles of ManzanillaAloreña cracked green table olives in different chloride salt mixtures. Food Microbiol. 27:403-412.

11. Betts, G. D., P. Linton, and R. J. Betteridge. 1999. Food spoilage yeasts: effects of $\mathrm{pH}, \mathrm{NaCl}$, and temperature on growth. Food Control 10:27-33.

12. Beuchat, L. R. 1998. Surface decontamination of fruits and vegetables eaten raw: a review. Food safety issues. World Health Organization, Food Safety Unit, Geneva.

13. Borcaklı, M., G. Ozay, I. Alperden, E. Ozsan, and Y. Erdek. 1993. Changes in chemical and microbiological composition of two varieties of olive during fermentation. Grasas Aceites 44:253-258.

14. Brul, S., and P. Coote. 1999. Preservative agents in foods. Mode of action and microbial resistance mechanisms. Int. J. Food Microbiol. 50:1-17.

15. Caponigro, V., M. Ventura, I. Chiancone, L. Amato, E. Parente, and F. Piro. 2010. Variation of microbial load and visual quality of readyto-eat salads by vegetable type, season, processor and retailer. Food Microbiol. 27:1071-1077.

16. Cardoso, S. M., I. Mafra, A. Reis, D. M. R. Georget, A. C. Smith, K. W. Waldron, and M. A. Coimbra. 2008. Effect of dry-salted processing on the textural properties and cell wall polysaccharides of cv. Thasos black olives. J. Sci. Food Agric. 88:2079-2086.

17. Coton, E., M. Coton, D. Levert, S. Casaregola, and D. Sohier. 2006. Yeast ecology in French cider and black olive natural fermentations. Int. J. Food Microbiol. 108:130-135.

18. Değirmencioğlu, N. 2011. Influence of temperature and modified atmosphere on the microbial profile of packed Gemlik dry-salted olives. J. Food Saf. 31:115-124.

19. Değirmencioğlu, N., O. Gürbüz, A. Değirmencioğlu, Y. Şahan, and H. Özbey. 2011. Effect of MAP and vacuum sealing on sensory qualities of dry salted olive. Food Sci. Biotechnol. 20:13071313.

20. Delaquis, P. J., L. R. Fukumoto, P. M. A. Toivonen, and M. A. Cliff. 2004. Implications of wash water chlorination and temperature for the microbiological and sensory properties of fresh-cut iceberg lettuce. Postharv. Biol. Technol. 31:81-91.

21. Doyle, M. E. 2008. Sodium reduction and its effects on food safety, food quality, and human health: a brief review of the literature. Food Research Institute, University of Wisconsin-Madison.

22. Eswaranandam, S., N. S. Hettiarachchy, and M. G. Johnson. 2004. Antimicrobial activity of citric, lactic, malic, or tartaric acids and nisin-incorporated soy protein film against Listeria monocytogenes, Escherichia coli O157:H7 and Salmonella Gaminara. J. Food Sci. 69: 79-84.

23. Food and Agriculture Organization of the United Nations. 2010. Processing of fresh-cut tropical fruits and vegetables: a technical guide. RAP publication 2010/16. Food and Agriculture Organization of the United Nations, Regional Office for Asia and the Pacific, Bangkok.

24. Francis, G. A., C. O. Thomas, and D. Beirne. 1999. The microbiological safety of minimally processed vegetables. Int. J. Food Sci. Technol. 34:1-22.

25. Garrido-Fernández, A., M. J. Fernandez-Diez, and M. R. Adam. 1997. Olives and table olives, p. 10-21. In A. Garrido Fernández, M. J. Fernandez-Diaz, and M. R. Adams (ed.), Table olives: production and processing, 1st ed. Chapman \& Hall, London.
26. Garrido-Fernández, A., P. García-García, and M. Brenes Balbuena. 1995. Olive fermentation, p. 593-627. In H. J. Rhem and G. Reed (ed.), Biotechnology: enzymes, biomass, food, and feed. VHC, New York.

27. Guillou, A. A., J. D. Floros, and M. A. Cousin. 1992. Calcium chloride and potassium sorbate reduce sodium chloride used during natural cucumber fermentation and storage. J. Food Sci. 57:1364 1368 .

28. Harris, L. J. 1998. The microbiology of vegetable fermentation, p. 45-72. In J. B. B. Wood (ed.), Microbiology of fermented foods, 2nd ed. Blackie Academic and Professional, London.

29. Hernández, A., E. Martín, F. Aranda, and M. G. Pérez Nevado. 2007. Identification and characterization of yeasts isolated from the elaboration of seasoned green table olives. Food Microbiol. 24: 346-351.

30. Hurtado, A., C. Reguant, B. Esteve-Zarzozo, A. Bordons, and N. Rozes. 2008. Microbial population dynamics during the processing of Arbequina table olives. Food Res. Int. 41:738-744.

31. International Olive Council. 2011. World table olive figures. Available at: http://www.internationaloliveoil.org/estaticos/view/ 132-world-table-olive-figures. Accessed 5 November 2013.

32. Irtwange, S. W. 2006. Application of modified atmosphere packaging and related technology in postharvest handling of fresh fruits and vegetables. Agric. Eng. Int. 8:1-13.

33. Jimenez, A., R. Rodriguez, I. Fernandez-Caro, R. Guillen, J. Fernandez-Bolanos, and A. Heredia. 2000. Dietary fiber content of table olives processed under different European styles: study of physico-chemical characteristics. J. Sci. Food Agric. 80:19031908.

34. Jongen, W. 2005. Alternatives to hypochlorite washing systems for the decontamination of fresh fruit and vegetables, p. 351-372. In W. Jongen (ed.), Improving the safety of fresh fruit and vegetables. Woodhead Publishing and CRC Press, Cambridge.

35. Mocak, J., A. M. Bond, S. Mitchell, and G. Schollary. 1997. A statistical overview of standard (IUPAC and ACS) and new procedures for determining the limits of detection and quantification: application to voltammetric and stripping techniques. IUPAC technical report 1997. Pure Appl. Chem. 69:297-328.

36. Panagou, E. Z. 2004. Effect of different packing treatments on the microbiological and physicochemical characteristics of untreated green olives of the 'Conservolea' cultivar. J. Sci. Food Agric. 84: 757-764.

37. Panagou, E. Z. 2006. Greek dry-salted olives: monitoring the drysalting process and subsequent physico-chemical and microbiological profile during storage under different packing conditions at 4 and $20^{\circ}$ C. LWT Food Sci. Technol. 39:323-330.

38. Panagou, E. Z., U. Schillinger, C. M. Franz, and G.-J. Nychas. 2008. Microbiological and biochemical profile of $\mathrm{cv}$. Conservolea naturally black olives during controlled fermentation with selected strains of lactic acid bacteria. Food Microbiol. 25:348-358.

39. Panagou, E. Z., C. C. Tassou, and K. Z. Katsaboxakis. 2002. Microbiological, physicochemical, and organoleptic changes in drysalted olives of Thasos variety stored under different modified atmospheres at 4 and $20^{\circ}$ C. Int. J. Food Sci. Technol. 37:635-641.

40. Pianetti, A., L. Sabatini, B. Citterio, L. Pierfelici, P. Ninfali, and E. Bruscolini. 2008. Changes in microbial populations in ready-to-eat vegetable salads during shelf life. Ital. J. Food Sci. 20:245-254.

41. Ramos, B., F. A. Miller, T. R. S. Brandão, P. Teixeira, and C. L. M. Silva. 2013. Fresh fruits and vegetables-an overview on applied methodologies to improve its quality and safety. Innov. Food Sci. Emerg. Technol. 20:1-15.

42. Raybaudi-Masilia, R. M., J. Mosqueda-Melgar, R. Soliva-Fortuny, and O. Martin-Belloso. 2009. Control of pathogenic and spoilage microorganisms in fresh-cut fruits and fruit juices by traditional and alternative natural antimicrobials. Compr. Rev. Food Sci. Food Saf. 8: $157-180$.

43. Ricke, S. C. 2003. Perspectives on the use of organic acids and short chain fatty acids as antimicrobials. Poult. Sci. 82:632-639.

44. Rodríguez-Gómez, F., F. N. Arroyo-López, A. López-López, J. Bautista-Gallego, and A. Garrido-Fernández. 2010. Lipolytic activity 
of the yeast species associated with the fermentation/storage phase of ripe olive processing. Food Microbiol. 27:604-612.

45. Rodríguez-Gómez, F., V. Romero-Gil, J. Bautista-Gallego, A. Garrido-Fernández, and F. N. Arroyo-López. 2012. Multivariate analysis to discriminate yeast strains with technological applications in table olive processing. World J. Microbiol. Biotechnol. 28:17611770.

46. Sanchez-Gomez, A. H., P. García-García, and L. Rejano-Navarro. 2006. Elaboration of table olives. Grasas Aceites 57:86-94.

47. Simons, L. L., and P. Sanguansri. 1997. Advances in the washing of minimally processed vegetables. Food Aust. 49:75-80.

48. Tamer, C. E., V. Uylaşer, B. İncedayı, H. Vural, and Ö. U. Çopur. 2009. Hedonic price model of table olive in Turkish markets: a case study of Bursa Province. Not. Bot. Hort. Agrobot. Cluj 37:219223.

49. Tantaoui-Elaraki, A., S. Samane, and M. F. Roquebert. 1990 Mycoflora of Moroccan "Greek-style" black olives. I. Inventory. Microbiol. Aliment. Nutr. 8:257-264.

50. Taormina, P. J. 2010. Implications of salt and sodium reduction on microbial food safety. Crit. Rev. Food Sci. Nutr. 50:209-227.

51. Tassou, C. C., E. Z. Panagou, and K. Z. Katsaboxakis. 2002. Microbiological and physicochemical changes of naturally black olives fermented at different temperatures and $\mathrm{NaCl}$ levels in the brines. Food Microbiol. 19:605-615.
52. Tirpanalan, O., M. Zunabovic, K. J. Domig, and W. Kneifel. 2011. Antimicrobial strategies in the production of fresh-cut lettuce products, p. 176-188. In A. Méndez-Vilas (ed.), Science against microbial pathogens: communicating current research and technological advances, vol. 1. Formatex Research Center, Badajoż, Spain. Available at: http://www.formatex.org/microbiology3/chapters1.html. Accessed 13 October 2013.

53. Tokuoka, K. 1993. Sugar and salt-tolerant yeasts. J. Appl. Bacteriol. 74:101-110.

54. Tuna, S., and A. Akpinar-Bayizit. 2009. The use of $\beta$-glucosidase enzyme in black table olives fermentation. Not. Bot. Hort. Agrobot. Cluj 37:182-189.

55. U.S. Food and Drug Administration. 2013. Secondary direct food additives permitted in food for human consumption. Chlorine dioxide. 21 CFR 173.300. U.S. Food and Drug Administration, Silver Spring, MD.

56. Vaughn, R. H., T. Jakubcsyk, J. D. MacMillan, T. E. Higgins, B. A. Davé, and V. M. Crampton. 1969. Some pink yeasts associated with softening of olives. Appl. Microbiol. 18:771-775.

57. Vaughn, R. H., K. E. Stevenson, B. A. Davé, and H. C. Park. 1972. Fermenting yeasts associated with softening and gas-pocket formation in olives. Appl. Microbiol. 23:316-320.

58. Zagory, D. 1999. Effects of post-processing handling and packaging on microbial populations. Postharv. Biol. Technol. 15:313-321. 
Copyright of Journal of Food Protection is the property of Allen Press Publishing Services Inc. and its content may not be copied or emailed to multiple sites or posted to a listserv without the copyright holder's express written permission. However, users may print, download, or email articles for individual use. 